\title{
The Output Current Controller of a Single-phase Grid-connected PV Inverter in Discrete Fourier Transform
}

\author{
Uiseon Hwang, Oh Yang and Wonsup Chung \\ Electronic Engineering of Cheongju University \\ hoangkas@nate.com,ohyang@cju.ac.kr,circuit@cju.ac.kr
}

\begin{abstract}
The output current of grid-connected PV inverters should not excess harmonic contents. Also, because they are driven connected with grid, the reliability of electric power's quality should be secured. But, the current controllers of the grid-connected PV inverter decrease the electric power's quality due to not considering the harmonic contents of the output current. This paper proposed the current controllers of the grid-connected PV inverters to supplement the decrease of the electric power's quality because of the harmonic contents of the electric power's quality and the harmonic contents of the output current. The proposed current controllers controlled the harmonic contents of the output current by controlling gains of the current controllers in consideration of the harmonic contents of the output current. As a result, when total harmonic distributions of the grid voltage were $0.4 \%$ and $4.1 \%$, the excellence of the proposed current controllers was shown through the experience, by obtaining excellent results of being controlled low as the total harmonic distributions of the output current were $0.756 \%$ and $0.78 \%$ respectively.
\end{abstract}

Keywords: Discrete Fourier Transform, Total Harmonic Distortion, Current Controller, Single- Phase Grid-connected PV Inverter

\section{Introduction}

Nowadays, alternative energy studies are continued considering environmental pollution and resources' limited reserves. Interests and studies on generation systems using new renewable energies as the alternative energies are conducted actively. PWM inverters using high efficiency DSP are used a lot in power conversion systems and have a strong point that controlling of power factors and DC link voltage and decreasing the harmonic wave of output current. Owing to these, grid-connected power conversion systems have been developed rapidly. Also, because of high conversion efficiency, high reliability, and profitable prices, the grid-connected energy conversion systems' demands are increasing [1, 2, 3].

Generally, because photovoltaic power generation is low in energy conversion efficiency and nonlinear in output features, the maximum power point tracking (MPPT) control technology to obtain maximum electric power in solar cells, control technology of DC to DC converter to supply stable output of inverters, and output current's control technology are essential. Also, PLL control technology that grid voltage and output voltage of inverters can be controlled into the same phase plays an important role in systems and interconnection operation $[4,5]$.

Lots of control technologies about the grid-connected PV inverters were studied to secure improvement of power quality, stability of systems, high efficiency, and reliability. Especially, the reliability of power quality should be considered and a control to improve the power quality is necessary [6]. The harmonic contents of the output current occur due to two causes. 
First, when the grid voltage is distorted, the harmonic contents occur. Second, due to a false design of an output current control, the harmonic contents occur. The commercial power source is not ideal grid voltage having the low harmonic contents. Because the harmonic contents of the grid voltage are different country to country and region to region. The harmonic contents of inverter output current are regulated by IEEE standard. The harmonic order of the output current should be controlled 3\% and under, total harmonic distribution be controlled 5\% and under, and the power factor be controlled 0.95 and over. The gridconnected PV inverters generally consist of a proportional integral(PI) control and a proportional resonant(PR) control [6,7]. Because of a weak point that the optimal gaining of a proportional integral control is difficult and generally the gain of the a proportional integral controllers is used to be fixed, the compensation of consideration of the harmonic contents of output current cannot be done and the quality of power decreases.

This paper proposed that output current controllers considering the harmonic contents of output current, to supplement controllers based on PI used a lot previously as output current controllers of the grid-connected PV inverters. Using DFT algorithm, the harmonic waves from first to ninth order of output current were detected. And total harmonic distribution of output was calculated. By controlling gains of the output current controllers automatically with the total harmonic distribution of output, the output current was controlled. The power quality is intended to be increased by applying the proposed output current controllers to the grid-connected PV inverters.

\section{Grid-connected PV Inverter}

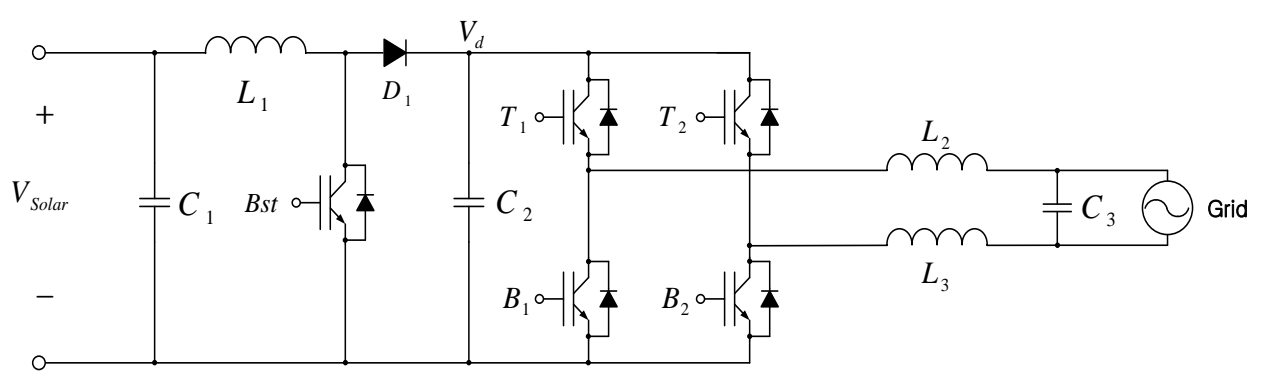

Figure 1. Structure of the grid-connected PV inverter

The Figure 1 is a representative construction drawing of the grid-connected PV inverter and it consists of a DC to DC converter and a DC to AC inverter. The DC to AC inverter is composed of H-bridge with high PWM frequency. The PWM frequency was set to $16.8 \mathrm{kHz}$. The DC to AC inverter having high PWM frequency changes direct current of the solar cells into grid current. AC current generates harmonic contents by LC filter, controllers of the PV inverters, and distortions of grid voltage. Distortion of output current incurs a bad influence on a system connected with the grid voltage and a transmission network by reducing power quality. So, the grid-connected PV inverters should be controlled for the harmonic contents to be generated low. To heighten the power quality, a maximum power point tracking control to always maintain maximum power, PLL control reducing reactive power by controlling grid voltage and inverter output voltage into same phase, and an output current controller to control output current stably are necessary. 


\subsection{Maximum Power Point Tracking (MPPT)}

The grid-connected PV inverters should always generate maximum power from nonlinear solar cells, and a stable control is necessary. If maximum power is not tracked or unstable, output current becomes unstable and power quality decreases. Current features of solar cells can be expressed as follows

$$
I_{\text {solar }}=I_{q}-I_{\text {sat }}\left\{\exp \left[\frac{\mathrm{q}\left(\mathrm{V}_{\text {solar }}+\mathrm{I}_{\text {solar }} \mathrm{R}_{\mathrm{s}}\right.}{\mathrm{AKT}}\right]-1\right\}
$$

where $\mathrm{I}_{\mathrm{q}}$ is light generated current, $\mathrm{I}_{\mathrm{sat}}$ is the saturation current of solar cell, $\mathrm{K}$ is Boltzmann's constant, A is ideality factor of the $\mathrm{p}-\mathrm{n}$ junction, $\mathrm{T}$ is temperature of solar cell, and $R_{S}$ is intrinsic series resistance of the solar cell. In these features of nonlinear solar cell, to generate the maximum power, the PV inverters use the maximum power point tracking control technology. Generally though there are a P\&O method and an IncCond method, some losses of solar cells come to occur by not tracking onto the drastic solar radiation or continuous microseism [8]. This paper applied a hysteresis method to supplement the existing the maximum power point tracking control method. The hysteresis method tracks maximum power by converting pulse widths of the boost converters. If the power reduces as much as ripple power based of the maximum power point, by increasing or decreasing pulse widths of the boost converters, they track fast and exactly. Figure 2 is an algorithm of the maximum power point tracking.

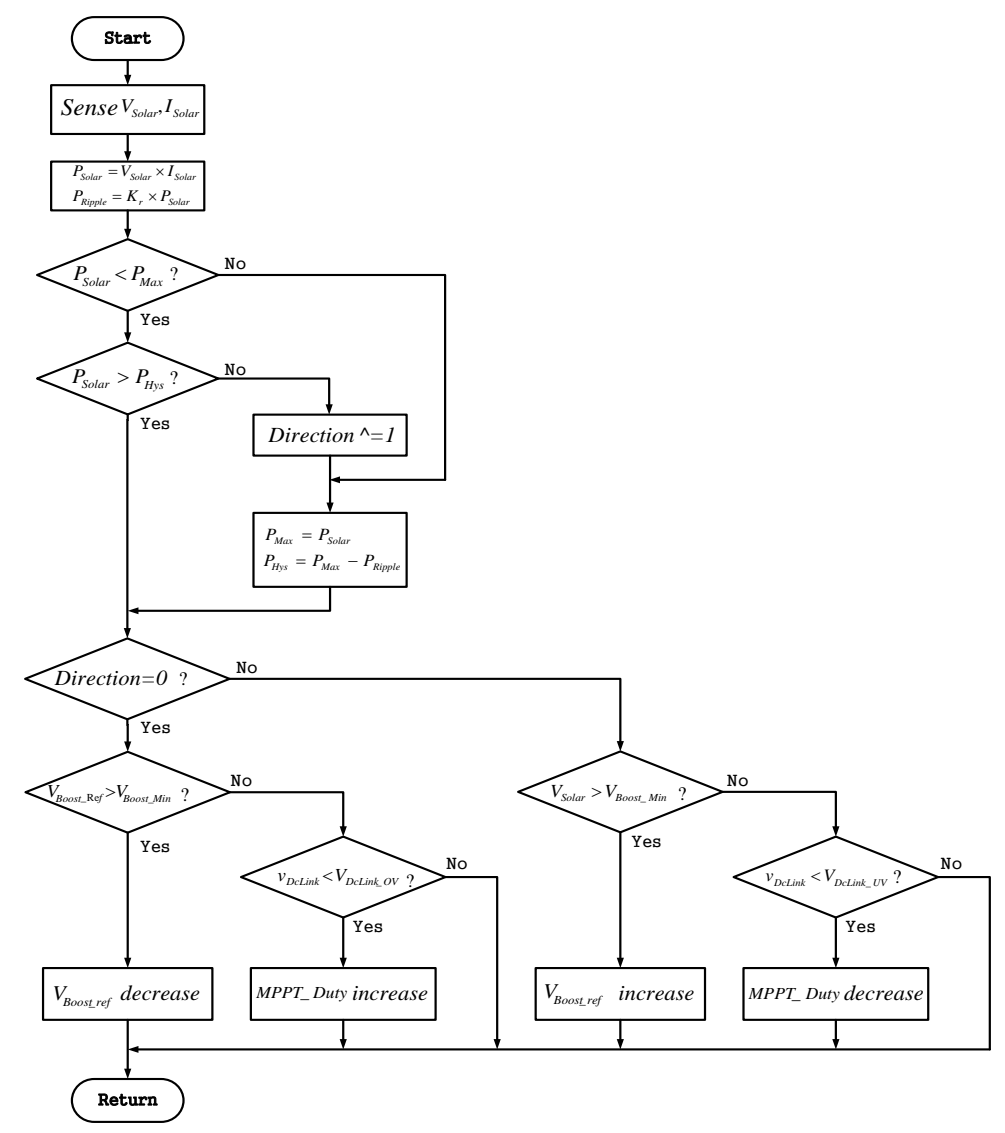

Figure 2. Flowchart of MPPT algorithm 


\subsection{Phase Locked Loop}

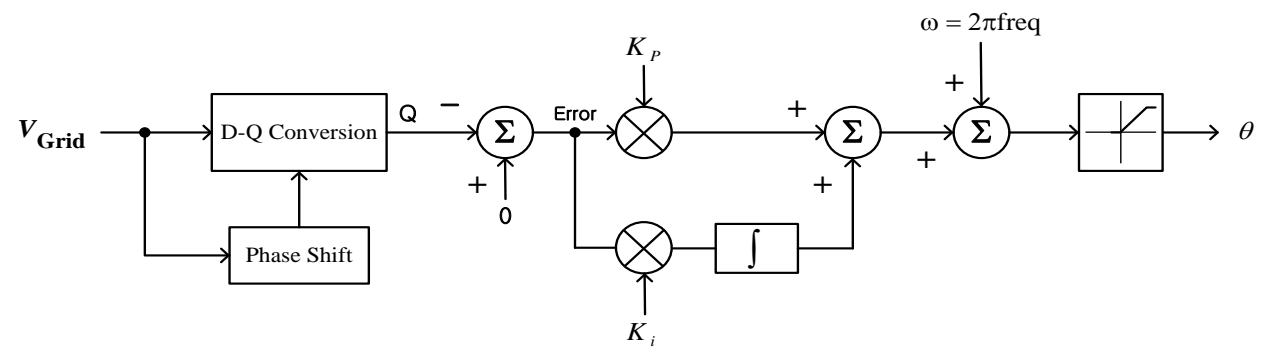

Figure 3. Block diagram of PLL

The PLL controllers were composed in Figure 3. The PLL controllers which were used in the grid-connected PV inverters used a detecting means of virtual two phases. By converting the grid voltage and D-Q of the virtual voltage that the grid voltage was moved $90^{\circ}$, they can be shown into D and Q axis and they can be expressed as follows

$$
\begin{aligned}
& \mathrm{V}_{\mathrm{d}}^{\mathrm{e}}=\mathrm{V}_{\mathrm{m}}\left(\cos \theta^{\prime} \cos \theta+\sin \theta^{\prime} \sin \theta\right)=\mathrm{V}_{\mathrm{m}} \cos \left(\theta-\theta^{\prime}\right) \\
& \mathrm{V}_{\mathrm{q}}^{\mathrm{e}}=\mathrm{V}_{\mathrm{m}}\left(-\cos \theta^{\prime} \sin \theta+\sin \theta^{\prime} \cos \theta\right)=\mathrm{V}_{\mathrm{m}} \sin \left(\theta-\theta^{\prime}\right)
\end{aligned}
$$

where $\mathrm{D}$ axis $\left(\mathrm{V}_{\mathrm{d}}^{\mathrm{e}}\right)$ is a real axis, $\mathrm{Q}$ axis $\left(\mathrm{V}_{\mathrm{q}}^{\mathrm{e}}\right)$ is an image axis and $\mathrm{V}_{\mathrm{m}}$ is the amplitude of grid voltage. Thus, with PI controller's input in Q axis, by controlling as 0 in phase difference of grid voltage and controlled phase, the phase of grid voltage can be tracked. Through PLL control, it is possible to track the phase of grid voltage and an invalid power of the PV inverter does not occur $[9,10]$.

\section{Discrete Fourier Transform (DFT)}

All cycles' signals are expressed sine waves deciding frequencies and the sine waves' sum as their integral multiple. They can be expressed as follows

$$
\begin{aligned}
& x(\mathrm{t})=\mathrm{a}_{0}+\sum_{\mathrm{k}=1}^{\infty} \mathrm{a}_{\mathrm{k}} \cos \mathrm{k} \omega_{0} \mathrm{t}+\sum_{\mathrm{k}=1}^{\infty} \beta_{\mathrm{k}} \sin \mathrm{k} \omega_{0} \mathrm{t} \\
& x(\mathrm{t})=\alpha_{0}+\sum_{\mathrm{k}=-\infty}^{\infty} x_{\mathrm{k}}^{\mathrm{j} \omega_{0} \mathrm{t}}
\end{aligned}
$$

where $\alpha_{\mathrm{k}}$ and $\beta_{\mathrm{k}}$ are a coefficient, $\omega_{0}$ is angular velocity. Discrete fourier transform means fourier transform for discrete signals and can analyze the grid voltage as AC signals and the harmonic contents of the grid current in the grid-connected PV inverters. This paper will analyze the output current of the grid-connected PV inverters using DFT and analyze the harmonic contents from first to ninth order and find the total harmonic distribution. If discrete signals of $\mathrm{N}$ number are given, they can be represented as follow

$$
X_{k}=\sum_{n=0}^{N-1} x_{n} \mathrm{e}^{-\frac{2}{N} j k n} \quad, k=0,1,2,3, \ldots \ldots . N-1
$$


where $\mathrm{N}$ is a sampling number of a cycle, $x_{\mathrm{n}}$ is consecutive discrete complex $\mathrm{N}$ values, $\mathrm{X}_{\mathrm{K}}$ is the discrete Fourier transformed value which was transformed into complex value. If it is represented into real parts $(\operatorname{ReX}[\mathrm{k}])$ and imaginary parts $(\operatorname{ImX}[\mathrm{k}])$, expanding (6) into an Euler formula, they can be expressed as follows [11]

$$
\begin{aligned}
& \mathrm{X}_{\mathrm{k}}=x_{\mathrm{n}}\left[\sum_{\mathrm{n}=0}^{\mathrm{N}-1} \cos \frac{2 \pi \mathrm{kn}}{\mathrm{N}}-\mathrm{j} \sin \frac{2 \pi \mathrm{kn}}{\mathrm{N}}\right] \\
& \operatorname{ReX}[\mathrm{k}]=\sum_{\mathrm{n}=0}^{\mathrm{N}-1} x_{\mathrm{n}} \cos \frac{2 \pi \mathrm{kn}}{\mathrm{N}} \\
& \operatorname{ImX}[\mathrm{k}]=\sum_{\mathrm{n}}^{\mathrm{N}-1} x_{\mathrm{n}} \sin \frac{2 \pi \mathrm{kn}}{\mathrm{N}} .
\end{aligned}
$$

The harmonic contents of analog signals can be got by converging A/D to convert the gridconnected PV inverter as analog signals into digital signals, it can be expressed as follows

$$
\begin{array}{ll}
\mathrm{M}_{\mathrm{h}}[\mathrm{k}]=\frac{\sqrt{2} \times \sqrt{\operatorname{ReX}[\mathrm{k}]^{2}+\operatorname{ImX}[\mathrm{k}]^{2}}}{\mathrm{~N}} & (\mathrm{k}=1, \ldots \ldots, \mathrm{N}-2, \mathrm{~N}-1) \\
\text { Harmonic }[\mathrm{k}]=\frac{\left.\mathrm{M}_{\mathrm{h}}[\mathrm{k}]\right]}{\mathrm{M}_{\mathrm{h}}[1]} \times 100[\%] & (\mathrm{k}=1, \ldots \ldots, \mathrm{N}-2, \mathrm{~N}-1)
\end{array}
$$

where $\mathrm{M}_{\mathrm{h}}[\mathrm{k}]$ means the harmonic contents of $\mathrm{k}$ order of analog signals, $\mathrm{M}_{\mathrm{h}}[1]$ means fundamental wave contents and Harmonic $[\mathrm{k}]$ is percent of each degree for the fundamental wave. With the harmonic contents of each its order, total harmonic distribution (THD) of the analog signals can be got as follows

$$
\mathrm{THD}=\sqrt{\sum_{\mathrm{h}=1}^{\infty} \mathrm{M}_{\mathrm{h}}[\mathrm{k}]} / \mathrm{M}_{\mathrm{h}}[1] . \quad \quad(\mathrm{k}=1, \ldots \ldots, \mathrm{N}-2, \mathrm{~N}-1)
$$

\section{Proposed Output Current Controller of Inverter}

\subsection{Conventional Current Controller of Inverter}

A proportional integral controllers used a lot in automation systems. It is one of important controllers in the grid-connected PV inverters. The output current controllers of the gridconnected PV inverters are the optimized controlling technique by doing conversion compensation of interference contents and the grid voltage [12]. The structure of PI controllers is shown as follows

$$
\mu(t)=K_{p} e(t)+\int_{0}^{t} K_{i} e(\tau) d \tau .
$$




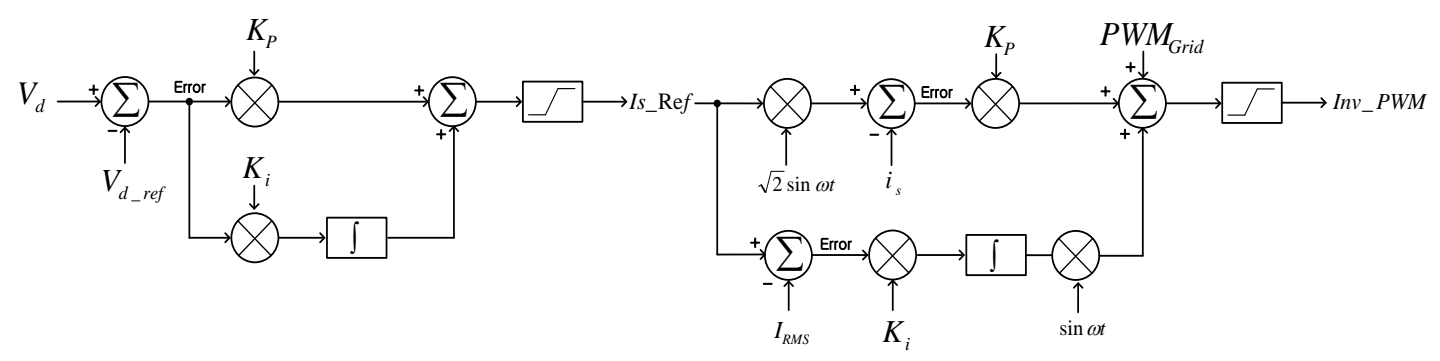

Figure 4. Block diagram of the conventional current controller

Figure 4 shows an existing structure of the output current controllers of the grid-connected PV inverters. The output current controllers were designed based on a proportional integral controllers. It is general to set gains of $\mathrm{P}$ by 10 times than gains of 1 . In designing a proportional integral controllers, it is difficult for $\mathrm{P}$ and I gains to get optimal gains. Also, considering outside disturbance as one gain, it is impossible to control that THD of the output current is $5 \%$ and under and each harmonic wave is $3 \%$ and under. Output controllers of the inverters are decided with the DC link voltage changes and come to regulate pulse widths of inverters as much as the output current's amounts. In the existing output current controllers of the grid-connected PV inverters, the harmonic contents in the grid voltage occur, and considerable level's harmonic contents occur due to gains of current controllers regulated in advance. Also, the harmonic contents of the output current can occur in a normal condition [9].

\subsection{Proposed Current Controller of Inverter}

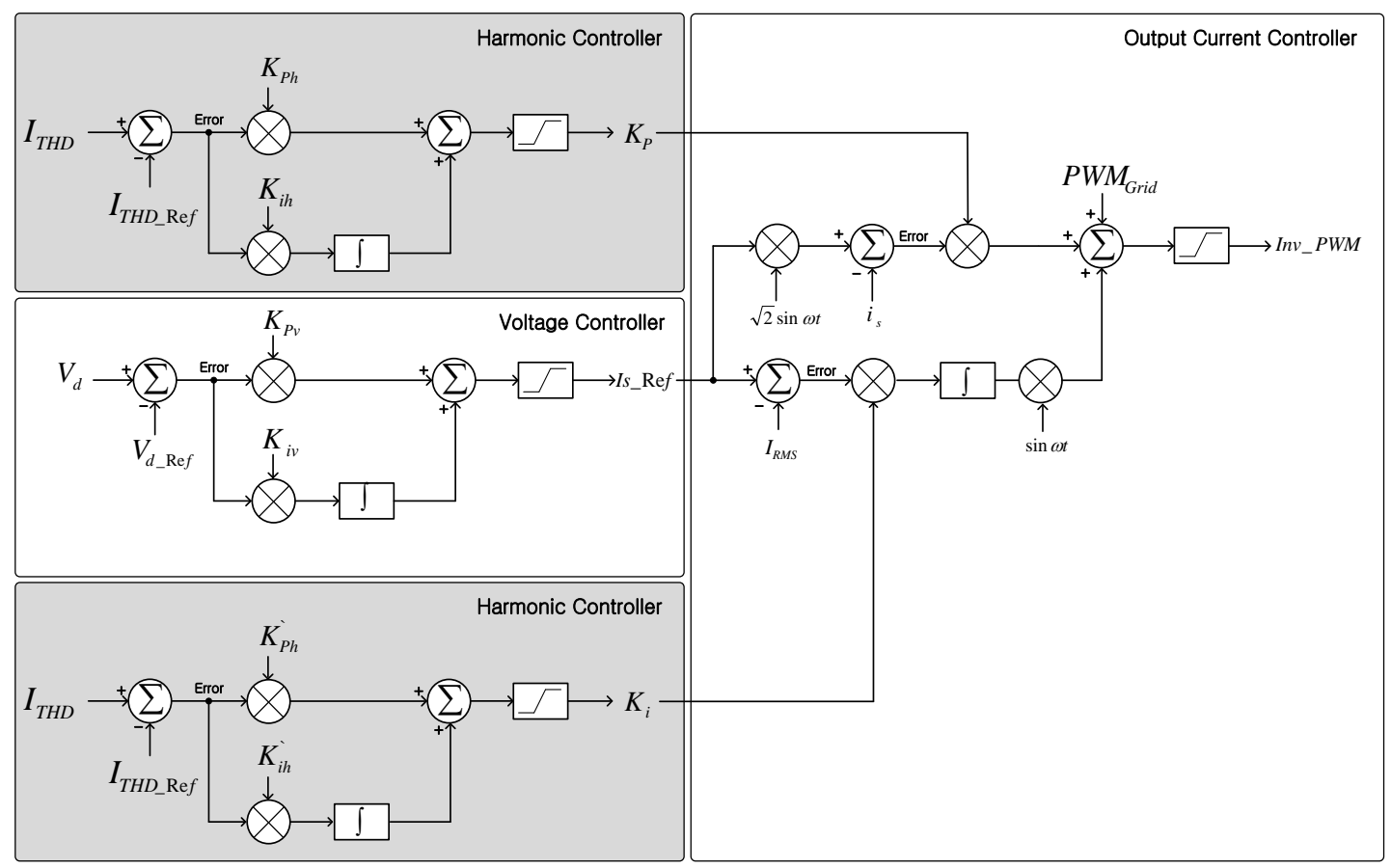

Figure 5. Block diagram of the proposed current controller 
The current controller considering the harmonic contents proposed in this paper improved the weak point that the harmonic contents cannot be lowered due to fixed gains of the conventional output current controllers when the harmonic contents of the grid voltage and inverter's output current occur. Also, as the amount of insolation is low, when generation amount is small, the harmonic contents of the output current occur a lot. So, being controlled high than regulated value of the harmonic contents of the output current was supplemented. Figure 5 is a structure of the proposed current controller. The basic structure is designed based on the conventional current controllers. The output current of the grid-connected PV inverters occur with the maximum power point tracking control. Namely, as the pulse widths of the boost converters through the maximum power point tracking control increase or decrease, with the changes of the voltage of DC link in the voltage controller in Figure 5, standard current of the inverter output current comes to be decided. Here, the P controller of the current controllers controls instantaneous value of the output current and the I controller controls the effective value. The proposed output current controller was added with the harmonic controllers in Figure 5 different from the conventional current controller in figure 4. The input of the harmonic controller analyzes the harmonic contents of the output current with DFT algorithm as the total harmonic distribution. And the harmonic distribution of the standard output current being a goal of PI control was set as an average value of the total harmonic distribution. The total harmonic distribution being the standard here was set from 0 to $2.5 \%$ and the harmonic contents of the output current could be controlled low. Output of the Harmonic controller can be expressed as follows

$$
\begin{aligned}
& \mathrm{k}_{\mathrm{p}}=\mathrm{K}_{\mathrm{ph}}\left(\mathrm{I}_{\mathrm{THD}}-\mathrm{I}_{\mathrm{THD} \_ \text {Ref }}\right)+\int_{0}^{\mathrm{t}} \mathrm{K}_{i \mathrm{~h}}\left(\mathrm{I}_{\mathrm{THD}}-\mathrm{I}_{\mathrm{THD} \_\mathrm{Ref}}\right) \mathrm{dt} \\
& \mathrm{k}_{i}=\mathrm{K}_{\mathrm{ph}}^{\prime}\left(\mathrm{I}_{\mathrm{THD}}-\mathrm{I}_{\text {THD_Ref }}\right)+\int_{0}^{\mathrm{t}} \mathrm{K}_{i \mathrm{~h}}^{\prime}\left(\mathrm{I}_{\mathrm{THD}}-\mathrm{I}_{\mathrm{THD}_{-} \mathrm{Ref}}\right) \mathrm{dt}
\end{aligned}
$$

where $\mathrm{I}_{\mathrm{THD}}$ is a measured value of the harmonic contents of the PV inverters' output current, $\mathrm{I}_{\text {THD_Ref }}$ is the standard value of the harmonic controller as an average value of the $\mathrm{I}_{\mathrm{THD}}$. Also, $\mathrm{K}_{\mathrm{Ph}}$ and $\mathrm{K}_{\mathrm{ih}}$ are the gain of the harmonic controller as $\mathrm{K}_{\mathrm{P}}$ in output. And, $\mathrm{K}_{\mathrm{Ph}}^{\prime}$ and $\mathrm{K}_{i \mathrm{~h}}^{\prime}$ are gains of the harmonic controller as $\mathrm{k}_{i}$ in output. Control speed of the harmonic controller is controlled per about $16.7 \mathrm{~ms}$. Namely, gains of the output current controller are controlled per cycle of the grid-voltage. The voltage controller can be expressed as follows

$$
\text { Is_Ref }=K_{p v}\left(V_{d}-V_{d \_R e f}\right)+\int_{0}^{t} K_{i v}\left(V_{d}-V_{d \_R e f}\right) d t
$$

where $V_{d}$ is measured of DC link voltage and $V_{d \_R e f}$ is a standard value of the DC link voltage. Inv_PWM as an output of the voltage controller is set as a standard current and the control speed is controlled per about 120us. The output current controller can be expressed as follows.

$$
\text { Inv_PWM }_{-}=\mathrm{K}_{\mathrm{p}}\left(\sqrt{2} \text { Is_Ref } \sin \theta-\mathrm{i}_{\mathrm{s}}\right)+\left(\int_{0}^{\mathrm{t}} \mathrm{K}_{i \mathrm{~V}}\left(\mathrm{Is} \_ \text {Ref }-\mathrm{I}_{\mathrm{RMS}}\right) \mathrm{dt}\right) \sin \theta+\operatorname{Grid}_{\mathrm{PWM}}
$$

where $\theta$ is an output of the PLL controller and $i_{s}$ is the measured instantaneous value of the output current. Also, $\mathrm{I}_{\mathrm{RMS}}$ is the effective value of the output current and Grid $_{\mathrm{PWM}}$ is changed into PWM level of the measured grid voltage 


\section{Experimental Results and Discussion}

This paper used a $4 \mathrm{~kW}$ single-phase grid-connected PV inverter. The single-phase gridconnected PV inverter is designed as the same structure of Figure 1. The output voltage of the PV inverter is $202 \mathrm{Vac}, 50 \mathrm{~Hz} / 60 \mathrm{~Hz}$ and a rated current of the PV inverter was set to be 19.8Aac. The input of the PV inverter was used TopCon Quadro of REGATRON company and SASControl as a simulator program instead of solar cells. Also, using real grid and 10kW AC source simulator, the excellence of the proposed current controller tried to be shown.

Table 1. The harmonic content of inverter current using DFT algorithm

\begin{tabular}{|c|c|c|c|c|c|c|}
\hline \multicolumn{3}{|c|}{ Precision power analyzer } & \multicolumn{3}{|c|}{ Proposed system } & \multirow[b]{2}{*}{$\begin{array}{c}\text { Difference } \\
\text { of error }\end{array}$} \\
\hline $\begin{array}{c}\text { Harmonic } \\
\text { order }\end{array}$ & Current & Harmonic & $\begin{array}{c}\text { Harmonic } \\
\text { order }\end{array}$ & Current & Harmonic & \\
\hline 1 & $20.121[\mathrm{~A}]$ & $100.0[\%]$ & 1 & $20.04[\mathrm{~A}]$ & $100.0[\%]$ & $0.0[\%]$ \\
\hline 2 & $32.408[\mathrm{~mA}]$ & $0.161[\%]$ & 2 & $41.38[\mathrm{~mA}]$ & $0.206[\%]$ & $0.045[\%]$ \\
\hline 3 & $59.917[\mathrm{~mA}]$ & $0.298[\%]$ & 3 & $65.74[\mathrm{~mA}]$ & $0.328[\%]$ & $0.03[\%]$ \\
\hline 4 & $22.371[\mathrm{~mA}]$ & $0.111[\%]$ & 4 & $32.79[\mathrm{~mA}]$ & $0.163[\%]$ & $0.052[\%]$ \\
\hline 5 & $135.64[\mathrm{~mA}]$ & $0.674[\%]$ & 5 & $118.19[\mathrm{~mA}]$ & $0.589[\%]$ & $0.085[\%]$ \\
\hline 6 & $19.819[\mathrm{~mA}]$ & $0.099[\%]$ & 6 & $20.11[\mathrm{~mA}]$ & $0.1[\%]$ & $0.001[\%]$ \\
\hline 7 & $47.565[\mathrm{~mA}]$ & $0.236[\%]$ & 7 & $44.53[\mathrm{~mA}]$ & $0.222[\%]$ & $0.014[\%]$ \\
\hline 8 & $7.3963[\mathrm{~mA}]$ & $0.037[\%]$ & 8 & $5.43[\mathrm{~mA}]$ & $0.027[\%]$ & $0.01[\%]$ \\
\hline 9 & $18.980[\mathrm{~mA}]$ & $0.094[\%]$ & 9 & $32.56[\mathrm{~mA}]$ & $0.162[\%]$ & $0.068[\%]$ \\
\hline THD & - & $0.810[\%]$ & THD & - & $0.814[\%]$ & $0.004[\%]$ \\
\hline
\end{tabular}
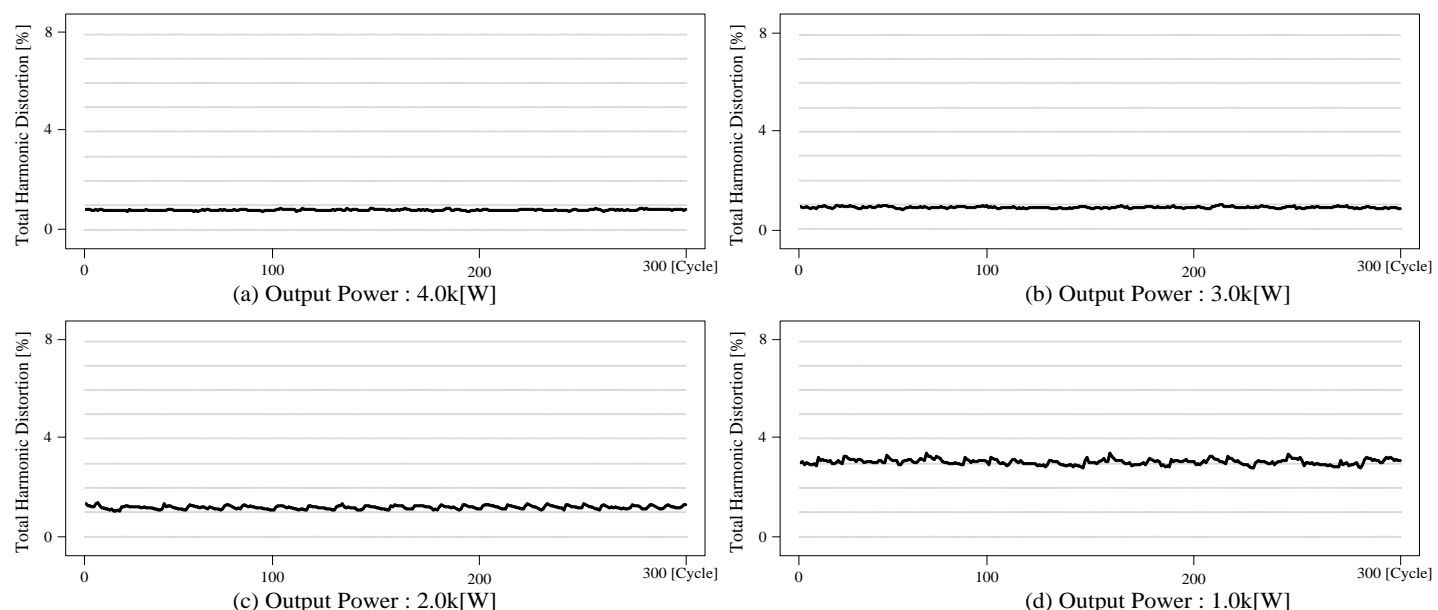

(c) Output Power : $2.0 \mathrm{k}[\mathrm{W}]$
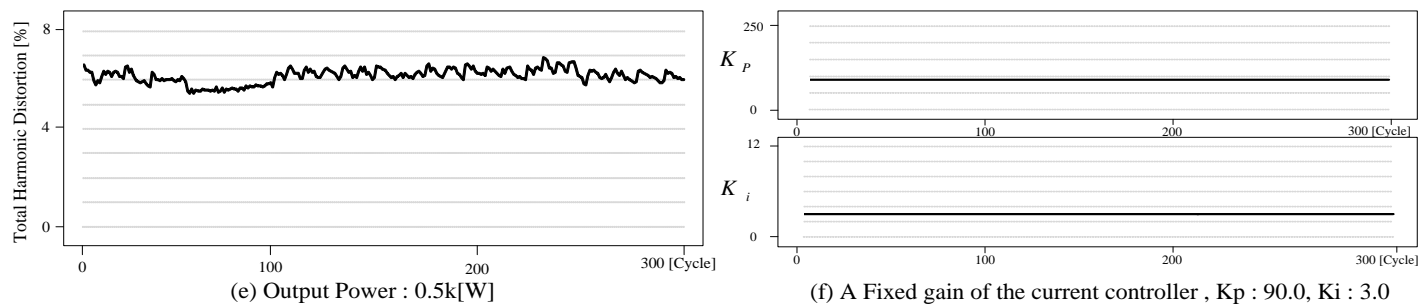

Figure 6. Experimental results of the conventional current controller 
Table 1 showed an analysis of the harmonic contents of the output current. Table 1 tried to show excellence of the proposed DFT algorithm compared with the harmonic contents measured with PPA5530 as a precision power analyzer of N4L company and the harmonic contents measured using the DFT algorithm. The PPA5530 as a precision power analyzer of N4L company is a highly precise measuring instrument with high-speed sampling of $1 \mathrm{M}$ sampling per sec, and error of 0.04\%. Freescale company's MK60FX512LQV15 was used as a DSP to measure the harmonic contents of the output current. For exact experiments, only DFT algorithm was applied and current control technique was not applied. A measured range of the inverter system was the harmonic contents from first to ninth degree as a basic wave of the output current, and the total harmonic distribution was found out. When the harmonic contents of the output current measured with the DFT are compared with the harmonic contents measured with PPA5530 as the precision power analyzer of N4L company, though delicate errors were there, precise measure value could be gained. So, using the DFT, by analyzing the harmonic contents of the output current, the harmonic contents of the output current can be known to be controlled precisely.

Figure 6 shows the total harmonic distribution of the output current when the conventional output current controllers are applied. The grid-connected PV inverters which applied the conventional output current controllers occur not only changes of the harmonic contents of the output current according to generation amount, but also 5\% of the total harmonic distribution and each $3 \%$ and more of harmonic wave. $4 \mathrm{~kW}$ as the maximum generation amount of the grid-connected PV inverter was set to be 100\%. In Figure 6, when the generation amount is $50 \%$, the total harmonic distribution was measured to be about $1 \%$. But, when the generation amount is $50 \%$ and under, the total harmonic distribution of the output current was measured to grow gradually. When the generation amount is $12.5 \%$, the total harmonic distribution of the output current was measured to be $5 \%$ and more and it was to be seen that power quality declined. Therefore, because the conventional current control technique does not consider the harmonic contents of the output current by using gains of controllers as fixed ones, power qualities of the grid-connected PV inverters were seen to decline.

\section{Table 2. Experimental results for conventional method and proposed method}

\begin{tabular}{ccccccc}
\hline \multirow{2}{*}{ Power } & \multicolumn{3}{c}{ The conventional method } & \multicolumn{3}{c}{ The proposed method } \\
\cline { 2 - 7 } & $\mathrm{k}_{\mathrm{P}}$ & $\mathrm{k}_{\mathrm{i}}$ & $\mathrm{THD}$ & $\mathrm{k}_{\mathrm{P}}$ & $\mathrm{k}_{\mathrm{i}}$ & THD \\
\hline \hline $4.0[\mathrm{~kW}]$ & & & $0.807[\%]$ & 84.4 & 2.1 & $0.779[\%]$ \\
$3.0[\mathrm{~kW}]$ & & & $0.881[\%]$ & 90.2 & 2.4 & $0.853[\%]$ \\
$2.0[\mathrm{~kW}]$ & 90.0 & 3.0 & $1.202[\%]$ & 110.6 & 9.7 & $1.055[\%]$ \\
$1.0[\mathrm{~kW}]$ & & & $3.061[\%]$ & 172.1 & 9.8 & $1.711[\%]$ \\
$0.5[\mathrm{~kW}]$ & & & $6.166[\%]$ & 245.5 & 9.9 & $2.488[\%]$ \\
\hline
\end{tabular}




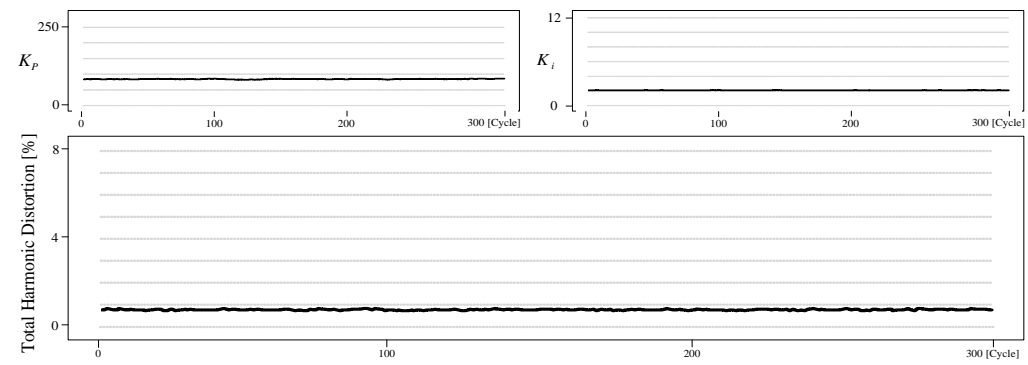

(a) Output Power : $4.0 \mathrm{k}[\mathrm{W}]$
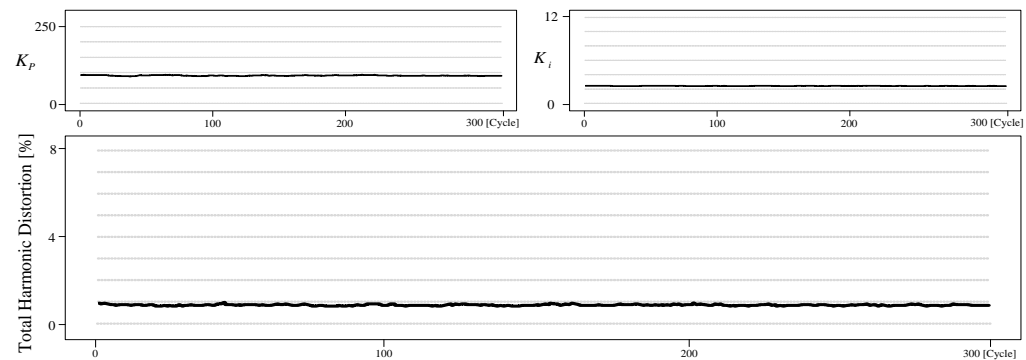

(b) Output Power : $3.0 \mathrm{k}[\mathrm{W}]$
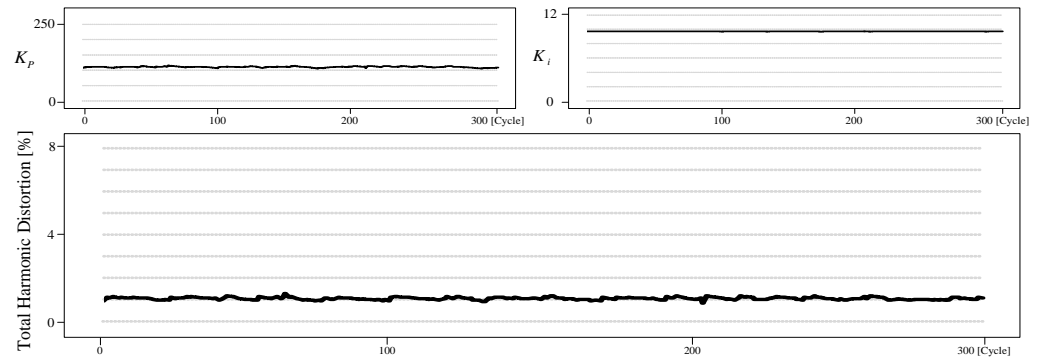

(c) Output Power : $2.0 \mathrm{k}[\mathrm{W}]$
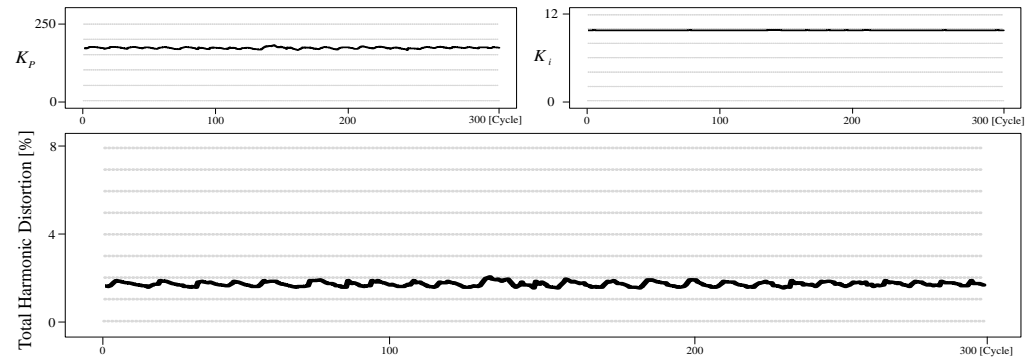

(d) Output Power : $1.0 \mathrm{k}[\mathrm{W}]$
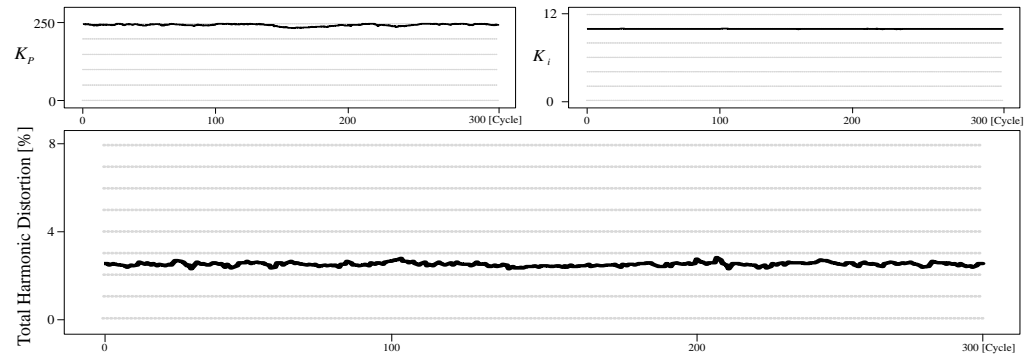

(e) Output Power : $0.5 \mathrm{k}[\mathrm{W}]$

Figure 7. Experimental results of the proposed current controller

Figure 7 shows the total harmonic distribution of the output current according to generation amounts, applying the proposed the current controller. In a condition of experiment of figure 6 , 
when the amount of generation is more than $50 \%$, the total harmonic distribution of the output current did not show big difference with the conventional method. But, gains of the power controller were controlled automatically; harmonic distribution of the output current was shown less than the conventional current control method. Also, when the amount of generation is less than $50 \%$, the total harmonic distribution occurred about $2.5 \%$. However, compared with the conventional method, through the proposed method, it was checked that $3.5 \%$ was controlled less. Additionally, since gains of the current controller were controlled considering the harmonic contents of the output current, it was checked that the harmonic contents of the output current was controlled low. Table 2 is experimental results for conventional method and proposed method.
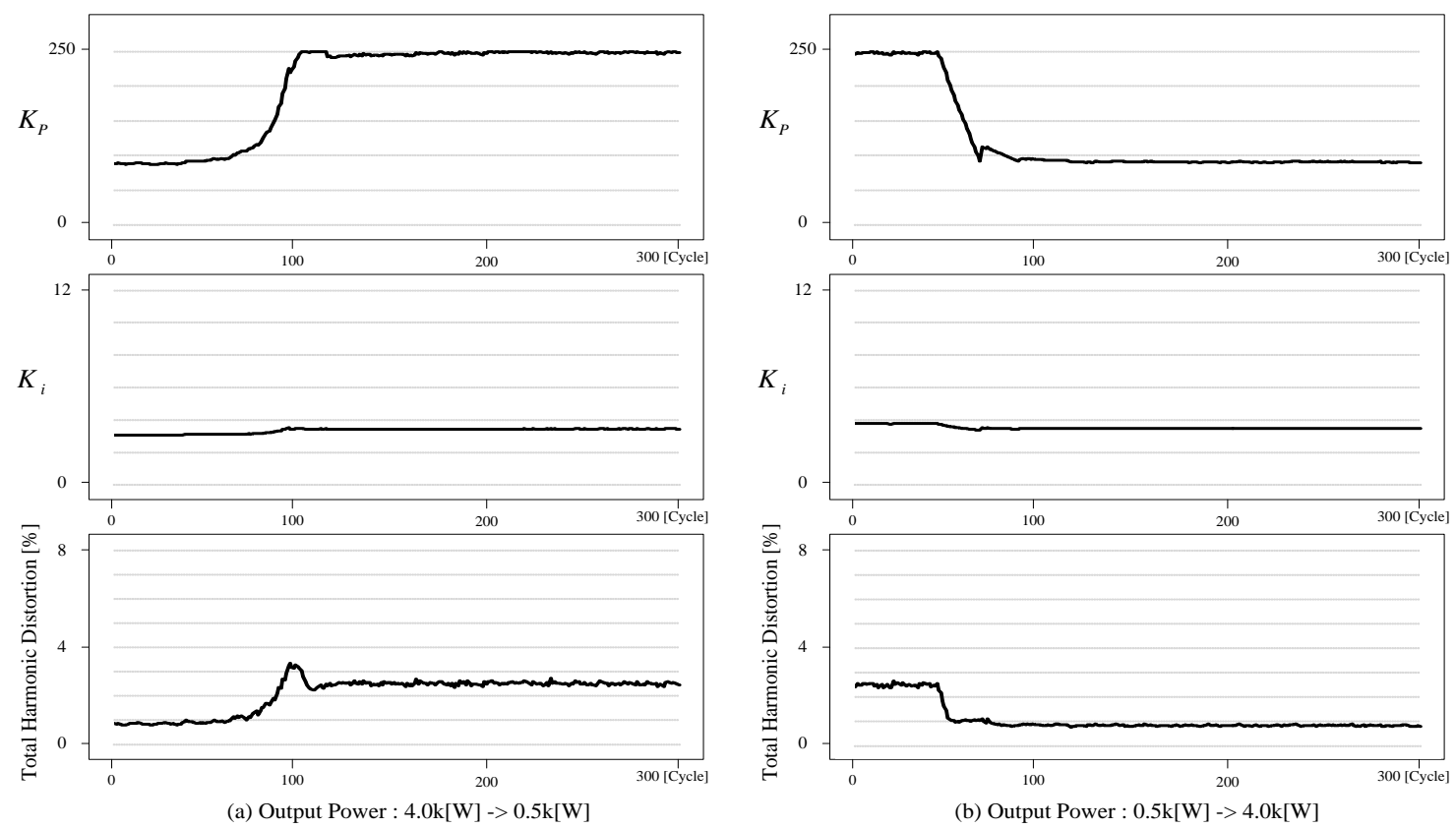

Figure 8. Power fluctuation experiment of inverter system

Figure 8 shows the proposed current controller's gains and a change of the output current's total harmonic distribution when the generation amounts of the grid-connected PV inverter were changed. The less were the generation amounts, the more occurred the harmonic contents of the output current. So, they should be controlled fast. When the generation amount was changed from $0.5 \mathrm{~kW}$ to $4 \mathrm{~kW}$ for a second, it was seen that the harmonic contents of the output current were controlled since gains of the current controller were applied fast. Also, when the generation amount was changed from $4 \mathrm{~kW}$ to $0.5 \mathrm{~kW}$, likewise it was checked that they were controlled fast. Thus, we can know that the harmonic contents of the output current were controlled fast and correctly considering the harmonic contents. 


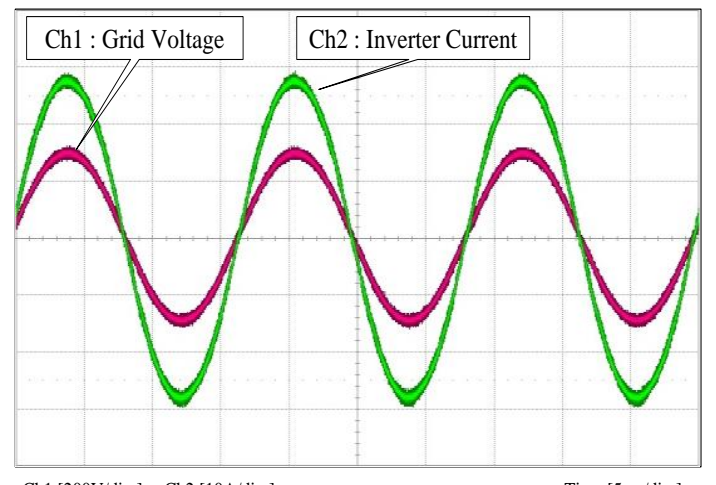

Ch1 [200V/div.] Ch2 [10A/div.]

(a) THD of Gird Voltage : $0.4 \%$

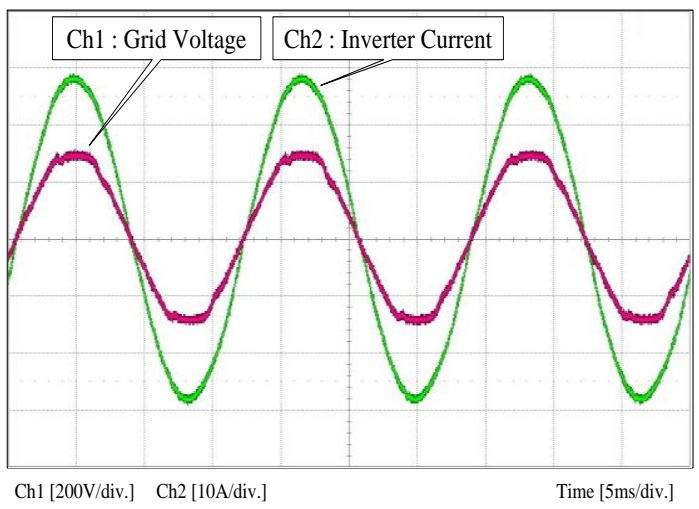

(b) THD of Gird Voltage : $4.1 \%$

Figure 9. Waveform of Grid Voltage and Output Current using Proposed Current Controller

Figure 9 is waveforms of the grid-connected PV inverters applied the current controllers which were proposed in the PV inverters, in the grid voltage that the harmonic contents were little and in the grid voltage that harmonic contents occurred a lot. In Figure 9(a), it was controlled like that the total harmonic distribution of the grid voltage was $0.4 \%$ and the total harmonic distribution of the output current was $0.756 \%$. In case of (b), it was controlled like that the total harmonic distribution of the grid voltage was $4.1 \%$ and the total harmonic distribution of the output current was $0.78 \%$. Therefore, the proposed current controllers output low harmonic contents' current, and the power quality increased regardless of the harmonic contents of the grid voltage.

\section{Conclusion}

This paper proposed the current controller of the grid-connected PV inverters. Since the conventional current controllers fix gains and do not consider the harmonic contents of the output current, the power quality declines. The proposed current controllers control considering the harmonic contents of the output current. Namely, by controlling gains of the current controllers automatically using the total harmonic distribution, they control the harmonic contents of the output current as less as possible. In this paper, to analyze the harmonic contents of the output current, they were measured applying the DFT algorithm. As a result that the total harmonic distribution was measured with the power analyzer and the DFT algorithm, precise measurement was shown like that the power analyzer was measured to be $0.81 \%$ and the DSP applied the DFT algorithm was measured to be $0.814 \%$. Also, regardless of the harmonic contents of the output current, the output current was controlled regularly. When the total harmonic distribution of the grid voltage was $0.4 \%$, the total harmonic distribution of the output current was controlled to be $0.756 \%$. When the total harmonic distribution of the grid voltage was $4.1 \%$, the total harmonic distribution of the output current was controlled to be $0.78 \%$. Therefore, the proposed current controllers could enhance the power quality of the grid-connected PV inverters by controlling the harmonic contents of the output current. 


\section{Acknowledgements}

This research was financially supported by the Ministry of Education, Science Technology (MEST) and National Research Foundation of Korea(NRF) through the Human Resource Training Project for Regional Innovation.

\section{References}

[1] M. Castilla, J. Miret, J. Matas, L. G. de Vicuna and J. M. Guerrero, "Linear current control Scheme With Serise Resonant Harmonic", Industrial Electronics, IEEE Transactions, vol. 55, (2008) July, pp. 2724-2733.

[2] G. Shen, X. Zhu, J. Zhang and D. Xu, "A New Feedback Method for PR current Control of LCL-Filter-Based Grid-Connected Inverter”, Industrial Electronics, IEEE Transactions, vol. 57, (2010) June, pp. 2033-2041.

[3] J. Dannehl, F. W. Fuchs, S. Hansen and P. B. Thogersen, "Investigation of Active Damping approaches for PI-Based current Control of Grid-connected Pulse Width Modulation Converters With LCL Filters", Industrial Applications, IEEE Transactions, vol. 46, (2010) July-August, pp. 1509-1517.

[4] S. -H. Ko, A. -R. Cho, D. -U. Kang, C. -S. Park, C. -H. Jeon and S. -R. Lee, "A Grid-interactive PV Generation System With the Function of the Power Quality Improvement", The Transactions of Korean Institute of Power Electronics, vol. 12, (2007) August, pp. 300-309.

[5] H. S. Mok, G. H. Choe, J. M. Lee, S. H. Kim and J. K. Ji, "Reduction Method of Harmonic Current by Distorted Grid Voltage in the Grid-connected Inverter", The Transactions of Korean Institute of Power Electronics, (2007) November, pp. 108-111.

[6] T. -J. Park, T. -W. Kim, S. Hee, J. -H. Lee, M. -H. Gan and H. -H. Lee, "Model Reference Adaptive Current Controller for Grid-connection Inverter", The Transactions of Korean Institute of Power Electronics, (2009) July, pp. 36-38.

[7] D. -G. Kim, J. -W. Choi and H. -G. Kim, "The Current Control of a Single-phase Grid-tie Photovoltaic PCS in Synchronous Frame", The Koean institute of electrical engineers, (2008) April, pp. 103-105.

[8] J. -M. Kwon, B. -H. Kwon and K. -H. Nam, "Grid-Connected Photovoltaic Multistring PCS With PV Current Variation Reduction Control. Industrial Electronics", IEEE Transactions, vol. 56, (2009) November, pp. 4381-4388.

[9] J. -B. Ahn, W. -G. Kim, K. -H. Hwang and J. -G. Park, "A Study on Tuning of current controller for Gridconnected Inverter Using Particle Swarm Optimization”, The institute of electrical engineers, vol. 11, (2004) November, pp. 671-679.

[10] J. -M. Kwon, B. -H. Kwon and K. -H. Nam, "Photovoltaic Power conditioning System With Line Connection", Industrial Electronics, IEEE Transactions, vol. 53, (2006) June, pp. 1048-1054.

[11] S. -H. Lee, F. -S. Kang, D. -H. Lee, S. -E. Cho, T. -W. Lee and S. -J. Park, "High Precise Measurement of Grid-Connected Inverter using DFT", The Transactions of the Korean Institute of Power Electronics, vol. 17, (2012) April, pp. 93-98.

[12] D. -S. Choi, J. -K. Jeong, J. -H. Lee, Y. -I. Son, K. -I. Kim and B. -M. Han, "PI Observer Design for GridConnected Inverter Current Control”, The Korean institute of electrical engineers, (2011) July, pp. 20-22.

\section{Authors}

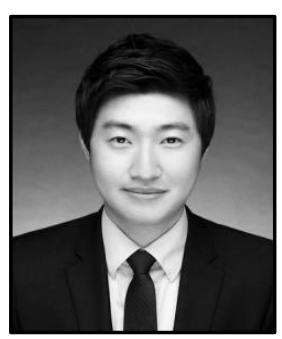

\section{Uiseon Hwang}

He received his B.A. degree in Semiconductor Engineering from Cheongju University, Korea, in 2012. He is currently working toward the M.S. degree in Electronic Engineering from Cheongju University, Korea. His research interests are converters for renewable energy and DSP control system 


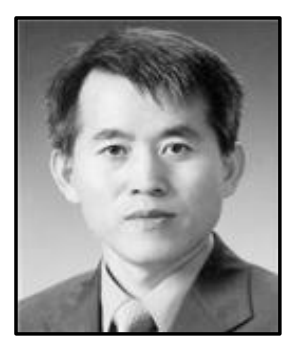

\section{Oh Yang}

He received his B.A., M.S., Ph.D. degree in Electrical Engineering from Han Yang University, Korea, in 1983, 1985, and 1997 respectively. From 1985 to 1997, he was research engineer at LGIS R\&D Lab. in the Department of Industrial Controller, An Yang, Korea. Since 1997, he has been with the Department of Electrical Engineering, Cheongju University, Korea. He was a visiting professor of A\&M University, Texas, USA, in 2006. He is currently a professor of the Semiconductor Engineering, Cheongju University, Korea. His research interests are converters for renewable energy, motor drives, power factor correction, and communication system for industrial controller.

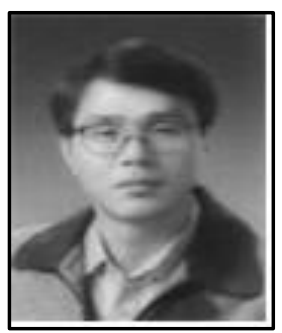

\section{Wonsup Chung}

He received his B.S., M.S. degree in Electrical Communication Engineering from Han Yang University, Korea, in 1977, 1979 respectively, and Ph.D. degree in Electrical Science Engineering, Shizuoka University, Japan, in 1986. He is currently a professor of the Semiconductor Engineering, Cheongju University, Korea. His research interests are Current-Mode analog signal processing, and sensor signal processing. 